\title{
KAJIAN INVESTASI IMPLEMENTASI PUSH E-MAIL DI PERUSAHAAN EPCC DENGAN METODE REAL OPTION VALUATION: STUDI KASUS PADA PT. REKAYASA INDUSTRI
}

\author{
Tri Hasmoro dan Benny Ranti
}

Fakultas Ilmu Komputer, Universitas Indonesia, Jakarta, Indonesia tri.hasmoro@gmail.com, ranti@infosolusi.co.id

\begin{abstract}
Abstrak
Kajian investasi adalah kegiatan analisis untuk menilai manfaat dan biaya dari suatu investasi, dan dapat dijadikan justifikasi investasi. Penilaian investasi yang tradisional menggunakan pendekatan finansial dimana manfaat dan biaya yang ada dikuantifikasi dalam sejumlah nilai uang dan kemudian dibandingkan besar nilainya. Hal inilah yang dilakukan pada metode penilaian investasi dengan NPV dan ROI. ROV (Real Option Valuation) adalah sebuah alternatif penilaian investasi secara finansial. Berangkat dari filosofi yang sama dengan Financial Option, ROV memiliki keunggulan dalam menangani fleksibilitas, resiko, dan volatilitas yang mungkin terjadi dari sebuah investasi. Dengan demikian ROV dinilai lebih mampu menghargai sebuah investasi yang memiliki karakteristik tersebut. Penilaian investasi dengan ROV lebih mampu mengapresiasi investasi dibanding metode finansial tradisional, seperti yang ditunjukkan hasil NPV ROV pada kasus investasi Push E-mail yang lebih besar daripada NPV biasa. Hal ini disebabkan ROV mampu menghargai fleksibilitas dalam investasi yang memiliki pilihan-pilihan rencana investasi di masa depan.
\end{abstract}

Kata kunci: Fleksibilitas, kajian investasi, NPV, ROI, ROV

\section{Pendahuluan}

Kajian investasi dilakukan untuk menjustifikasi pembiayaan sebuah investasi. Dalam kajian investasi, perkiraan biaya dan manfaat yang akan diperoleh dari suatu investasi dianalisa dan hasilnya digunakan untuk menentukan apakah investasi tersebut layak dilakukan atau tidak. Jika manfaat dari suatu investasi melebihi biayanya pada tingkat yang diharapkan oleh pengambil keputusan maka investasi itu akan dieksekusi dan jika tidak maka sebaliknya.

Secara tradisional pengkajian biaya dan manfaat investasi dilakukan dengan penilaian finansial. Beberapa contoh penilaian investasi dengan pendekatan finansial adalah ROI (Return On Investment), NPV (Net Present Value), dan DCF (Discounted Cash Flow). Pendekatan finansial memiliki kelemahan dalam menilai investasi yang sifatnya strategis seperti halnya TI (Teknologi Informasi). Investasi yang strategis biasanya mempunyai manfaat yang sulit diukur oleh perangkat finansial (intangible).

Terlepas dari itu, metode yang ada pun dinilai belum mampu menangkap nilai manfaat finansial yang sesungguhnya dari TI. Banyak kasus investasi TI yang tidak layak menurut penilaian finansial tradisional seperti yang telah disebutkan, namun ternyata layak pada kenyataannya. Hal ini disebabkan metode tersebut hanya menganalisa skenario tunggal terhadap masa depan rencana investasi [1]

Penjelasan di atas dapat disederhanakan dengan mengatakan bahwa metode tradisional gagal dalam menilai investasi TI karena mengabaikan nilai dari fleksibilitas. Akan tetapi kemudian muncul sebuah pendekatan penilaian investasi yang disebut real option yang mampu menciptakan portfolio pilihanpilihan atas investasi TI yang dapat diambil di masa depan sebagai tanggapan atas kondisi bisnis yang berubah-ubah.

Real option adalah adaptasi dari financial option untuk menilai investasi bukan saham. Financial option adalah sebuah kontrak untuk membeli atau menjual saham pada suatu waktu tertentu di masa depan. Kontrak ini hanya berupa hak dan bukan kewajiban sehingga tidak harus dieksekusi jika harga saham di masa depan tidak menguntungkan. Kemampuan financial option dalam menangkap fleksibilitas dan menangani resiko yang ada dalam investasi diadopsi dalam real option untuk menilai investasi bukan saham.

Konsep real option telah terbukti sejak pertengahan tahun 80-an di komunitas litbang industri farmasi untuk menentukan proyek mana yang harus didanai dan yang tidak, dan pada akhir tahun 90-an muncul gagasan penggunaan real option untuk menilai investasi TI. Penggunaan real option berakar 
dari premis bahwa setiap rencana adalah sebuah pilihan. Setiap proyek tetaplah berupa pilihan selama manajemen memiliki kebebasan untuk mempercepat, membatalkan, menunda, atau memperluas proyek. Kebebasan ini memiliki nilai yang bisa dianalisa secara kuantitatif. Metode penilaian investasi dengan real option ini disebut sebagai ROV (Real Option Valuation).

\section{Real Option Valuation}

Real option berasal dari kajian yang dilakukan untuk menentukan nilai sebuah financial option di dunia saham. Dalam financial option, suatu option adalah sebuah hak, dan bukan kewajiban, bagi pemegang option untuk melaksanakan transaksi (membeli atau menjual) saham. Di lain pihak option tersebut harus dilaksanakan oleh penjual option (option writer atau option seller), dan menjadi kewajiban mereka untuk membeli atau menjual sejumlah saham kepada pemegang option (option holder). Option dituangkan dalam bentuk kontrak antara penjual dan pemegang option untuk bertransaksi sejumlah saham pada harga tertentu di waktu kontrak tersebut jatuh tempo.

Ada dua jenis option, put dan call option. Call Option adalah hak untuk membeli saham yang diperoleh dengan cara pihak pemegang call terlebih dahulu membeli call option dari penjual call option dengan kesepakatan harga call, jangka waktu, dan harga saham pada waktu jatuh tempo (strike price). Investasi pemegang call akan kembali modal atau untung jika pada waktu jatuh tempo call, harga saham $\geq$ harga call + harga strike price, demikian sebaliknya untuk kerugian.

Put Option adalah hak untuk menjual saham yang diperoleh dengan cara pihak pemegang put terlebih dahulu membeli put option dari penjual put option dengan kesepakan harga put, jangka waktu dan harga pada waktu jatuh tempo (strike price). Investasi pemegang put akan kembali modal atau untung jika pada waktu jatuh tempo, harga saham $\leq$ harga strike price - harga put, dan kerugian akan di peroleh jika sebaliknya [2].

Untuk jenis option yang manapun baik put option maupun call option, nilai strike price yang menyebabkan kerugian tidak akan merugikan pemegang option. Jika terjadi hal demikian, pemegang option akan memilih untuk mengabaikan option dan tidak mengeksekusi isi kontraknya karena option adalah sebuah hak dan bukan kewajiban bagi pemegangnya. Dengan mengabaikan option, kerugian akan diminimalisasi hanya menjadi sebatas harga option yang dibeli.
Berdasarkan waktu eksekusinya, option dibagi menjadi tiga jenis:

1. European style

Eksekusi kontrak hanya dapat dilakukan pada waktu jatuh tempo atau saat kadaluarsanya.

2. American style

Eksekusi kontrak dapat dilakukan kapan saja sebelum masa kadaluarsa.

3. Bermudan style

Eksekusi kontrak hanya dapat dilakukan pada waktu-waktu tertentu sampai tibanya masa kadaluarsa.

Harga dari sebuah option pada waktu eksekusinya berada dalam salah satu dari tiga kemungkinan keadaan: in-the-money, at-the-money, atau out-of-themoney. Option yang in-the-money memiliki nilai intrinsik yang positif, yaitu option yang jika dieksekusi akan menghasilkan keuntungan berdasarkan kaidah yang telah dijelaskan sebelumnya. Option yang at-the-money adalah option yang akan impas ketika dieksekusi, sedangkan option yang out-of-the-money adalah option yang akan mendatangkan kerugian.

Berangkat dari dasar filosofi yang sama dengan financial option, real option didefinisikan sebagai sebuah hak, bukan kewajiban, untuk melaksanakan keputusan bisnis terutama dalam hal investasi. Sebagai contoh, kesempatan untuk berinvestasi dengan melakukan ekspansi perusahaan adalah sebuah real option. Berbeda dengan financial option, real option tidak dapat diperjualbelikan, jadi untuk kasus tersebut, pemilik perusahaan tidak dapat menjual haknya untuk mengekspansi perusahaan pada pihak lain. Dalam analisis untuk menghasilkan keputusan investasi, real option bersifat call option. Ini dikarenakan baik real option untuk berinvestasi maupun call option merupakan tindakan pengeluaran dana.

Keunggulan mendasar dari real option adalah bahwa dalam metode ini faktor volatilitas yang tinggi merupakan hal yang menguntungkan. Pendekatan metode finansial tradisional menganggap volatilitas yang tinggi memiliki resiko yang tinggi serta discount rate yang tinggi pula dan discount rate yang tinggi akan menurunkan nilai investasi. Dalam real option volatilitas yang tinggi mencerminkan value yang tinggi karena volatilitas yang tinggi menciptakan kemungkinan nilai masa depan yang semakin besar. Hal ini disebabkan kita hanya akan mengeksekusi sebuah option jika melebihi strike price yang diharapkan. Sementara itu, volatilitas dalam arti negatif tidak akan merugikan karena kita pasti tidak akan mengeksekusinya.

Penilaian investasi dengan real option disebut ROV (Real Option Valuation). ROV dapat dilakukan 
dengan 2 pendekatan, pendekatan model binomial dan pendekatan model option pricing Black-Scholes. Kedua model ini berasal dari penggunaannya untuk menilai financial option.

Dalam pendekatan binomial, peluang atau option yang ada dalam suatu investasi dimodelkan memiliki kemungkinan pencabangan menjadi dua cabang pada setiap interval waktu yang telah didefinisikan sebelumnya. Pencabangan menjadi dua ini memodelkan peningkatan dan penurunan nilai aset. Sebuah option diasumsikan untuk diambil dan dieksekusi jika nilai yang akan didapat dari option tersebut melebihi biaya yang dikeluarkan untuk mengeksekusinya. Selisih antara nilai yang akan didapat di masa depan dengan modal yang akan dikeluarkan pada suatu option disesuaikan dengan kemungkinan terjadinya option tersebut, kemudian didiskon ke masa sekarang (present value) untuk mendapatkan nilai dari option tersebut.

Pendekatan model option pricing Black-Scholes secara esensi dapat dilihat sebagai perluasan dari model binomial. Pada model ini, jumlah interval waktu antara saat ini dengan waktu eksekusi mendekati tak hingga atau selang waktu antar option mendekati nol. Model Black-Scholes memiliki keunggulan dalam kemudahan dalam implementasi dibanding pendekatan binomial, namun memiliki keterbatasan berasumsi yang menyebabkan pendekatan binomial yang fleksibel lebih disukai untuk beberapa kasus [3]. Untuk selanjutnya option yang bukan berada dalam domain financial option akan disebut pilihan.

\subsection{Model Black-Scholes}

Model Black-Scholes atau yang biasa disebut Black-Scholes adalah model harga instrumen finansial seperti saham yang nilainya selalu berubahubah seiring waktu. Pada tahun 1973, Fischer Black dan Myron Scholes mempublikasikan suatu model formula yang digunakan untuk menentukan nilai call option:

dimana:

$$
C=A N\left(d_{1}\right)-X e^{-r f T} N\left(d_{2}\right)
$$

$$
\begin{gathered}
d_{l}=\frac{\ln (A / X)+\left(r f+\left(\sigma^{2} / 2\right)\right) T}{\sigma \sqrt{ } T} \\
d_{2}=d_{l}-\sigma \sqrt{ } T
\end{gathered}
$$

$C=$ nilai call option

$A=$ nilai underlying asset

$X=$ nilai exercise price/strike price

$r_{f}=$ suku bunga bebas resiko

$T=$ jangka waktu kadaluarsa $\sigma=$ standar deviasi (variance) perubahan nilai

underlying asset (A)

$N=$ kumulatif standar distribusi normal

\subsection{Model Binomial}

Model Black-Sholes mengasumsikan ketidakpastian perubahan nilai saham $(A)$ terdistribusi secara lognormal. Dalam [4], nilai $A$ diasumsikan berubah-ubah mengikuti distribusi binomial. Gambar 1 adalah sebuah model binomial dari perubahan harga saham naik dengan faktor penurunan $u$ dan faktor peningkatan sebesar $d$.

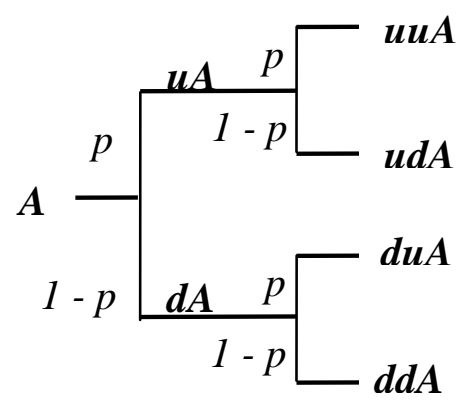

Gambar 1. Model Binomial

Dimulai pada waktu awal $t_{0}$, dalam suatu periode waktu $\Delta t$, nilai $A$ bisa meningkat menjadi $u A$ dengan probabilitas $p$ atau jatuh menjadi $d A$ dengan probabilitas $1-p$, dimana $d<1, u>1$, dan $d<r<u$, dengan $r=1+r_{f}$. Nilai $u$ didefinisikan sebagai $e^{\sigma . \sqrt{ } \Delta t}$ dan nilai $d=1 / u$.

Nilai akhir dari call option dari $A$ pada setelah $\Delta t$ adalah $C u=\max [0, u A-X]$ atau $C d=\max [0, d A-$ $X]$ dengan probabilitas masing-masing $p$ dan 1-p. Dengan nilai $p \equiv\left(e^{r f . \Delta t}-d\right) /(u-d)$, nilai dari call option adalah:

$$
\begin{aligned}
C & =\frac{p C u+(1-p) C d}{R} \\
& =\frac{p \max [0, u A-X]+(1-p) \max [0, d A-X]}{R}
\end{aligned}
$$

\subsection{Parameter ROV untuk Investasi TI}

Apapun model yang digunakan baik BlackScholes maupun binomial, ada lima parameter yang perlu diketahui untuk menilai investasi dengan ROV:

1. Risk-free interest rate.

Return on project yang diminta dan biasanya didasarkan pada suku bunga bebas resiko.

2. Exercise price

Exercise price sama halnya dengan strike price pada financial option, yaitu harga yang dibayarkan untuk membeli saham. Dalam real option, exercise price adalah biaya investasi. 
3. Time to expiration

Lamanya waktu sebelum sebuah keputusan mengambil pilihan dibuat.

4. Value of underlying asset

Ini adalah harga saham saat ini sedangkan dalam real option ini adalah nilai present value dari arus kas masuk yang diharapkan. Untuk kasus investasi traded asset, nilai arus kas masuk berdasarkan harga pasar dari aset sedangkan pada investasi non-traded asset nilai arus kas masuk bisa berupa peningkatan pendapatan atau penghematan yang terjadi.

5. Volatility

Volatility atau volatilitas adalah sebuah ukuran ketidakpastian akan nilai dari sebuah peluang di masa depan. Secara teori ini adalah perkiraan deviasi standar dari tingkat pertumbuhan nilai aset, sementara dalam investasi non-traded asset volatilitas adalah kemungkinan arus kas masuk yang akan didapat di masa depan.

Volatilitas ditentukan oleh dua macam resiko. Unique risk, atau yang disebut juga private risk, adalah resiko yang melekat secara internal pada setiap organisasi dan menjadi bagian dari hal yang dapat dikendalikan. Unique risk diekspresikan dalam probabilitas. Sebagai contoh, seberapa kemungkinan proyek TI akan gagal, atau kemungkinan firewall yang baru dapat dibobol hacker.

Mengestimasi unique risk merupakan masalah keahlian dan data. Statistik dari database milik sendiri maupun publik biasa digunakan oleh penaksir asuransi. Industri farmasi mengestimasinya dengan diagram perbandingan antara produk yang berhasil dan yang gagal.

Bentuk resiko yang kedua adalah market risk atau sistematic risk, yaitu resiko yang berada di lingkungan eksternal organisasi sehingga tidak bisa dikendalikan. Resiko ini mengurangi nilai aset. Contoh market risk adalah peluang kenaikan suku bunga bank, atau harga komoditas.

\subsection{Metodologi}

Menggunakan ROV untuk mengevaluasi proyek investasi TI melibatkan tiga langkah (Boer, 2002): menangkap dan merumuskan pilihan (framing), menganalisa pilihan (analyzing), dan mengeksekusi pilihan (acting).

\subsubsection{Perumusan Kerangka Pilihan}

Ini adalah proses mengidentifikasi dan mendefinisikan peluang yang ada dari sebuah investasi. Rencana TI perusahaan (IT Plan) dapat digunakan sebagai input proses ini.
Dalam [5] tahapan perumusan kerangka pilihan disebut application framing. Aktivitas ini dimulai dengan pemetaan masalah [6] untuk mengetahui faktor-faktor yang mempengaruhi keputusan serta rencana, waktu, dan pilihan yang diperlukan yang dipetakan pada tiga jenis pendekatan sikap: pesimis, hati-hati, dan optimis (lihat Tabel 1).

Tabel 1. Matriks Strategi

\begin{tabular}{|l|l|l|l|l|}
\hline Pendekatan & Faktor & Rencana & Waktu & Pilihan \\
\hline Pesimis & & & & \\
\hline Hati-hati & & & & \\
\hline Optimis & & & & \\
\hline
\end{tabular}

\subsubsection{Analisis Pilihan}

Analisis pilihan terbagi dalam 3 aktivitas, yaitu:

a. Menganalisa rencana bisnis. Analisis terhadap rencana bisnis akan memberikan informasi biaya dan payoff value dari investasi. Aktivitas ini disebut juga base scoping appraisal (deterministic appraisal) atau penilaian deterministik.

b. Menilai resiko. Menganalisa market risk dan unique risk yang akan menentukan nilai volatilitas. Pada kasus traded asset, market risk adalah volatilitas nilai aset yang diperjualbelikan sementara unique risk adalah probabilitas kesuksesan pelaksanaan investasi dari segi internal perusahaan. Aspek internal ini bisa mencakup kemampuan, kesiapan teknis, dan sumberdaya perusahaan. Data dan catatan historis investasi perusahaan bisa diacu untuk menentukan nilai unique risk.

c. Menerapkan algoritma pilihan. Dimulai dengan membuat menggambar struktur pohon keputusan dari ivestasi. Menghitung gross value setiap tahapan dari net value tahapan berikutnya, dengan menggunakan net value tersebut sebagai parameter underlying asset, dan biaya tahapan berikutnya sebagai strike price. Perhitungan ini dilakukan mundur dari present value pada rencana bisnis, yaitu gross value pada tahapan akhir, melalui tahapan-tahapan sebelumnya.

\subsubsection{Eksekusi Pilihan}

Sebuah pilihan akan dieksekusi jika nilainya "inthe-money", yaitu ketika nilai underlying asset melebihi strike price-nya yaitu ketika nilai payoff value melebihi biaya untuk mengeksekusinya. Pilihan yang diambil akan bergantung pada kondisi yang akan terjadi di masa depan. Skema metodologi digambarkan pada Gambar 2. 


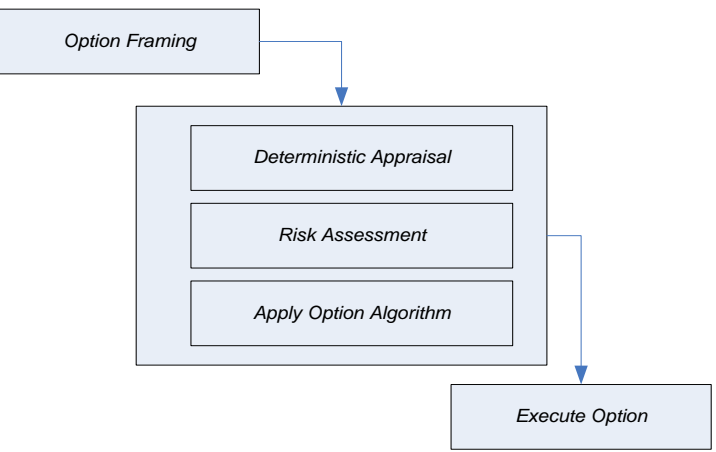

Gambar 2. Metodologi Real Option

\section{Kasus Investasi Push Email}

PT. Rekind (Rekayasa Industri) sebagai salah satu perusahaan EPCC (Engineering, Procurement Construction, and Commissioning) terbesar di Indonesia mencoba untuk mengimplementasikan push e-mail untuk membantu meningkatkan kinerja proses bisnisnya. Sebagai perusahaan yang memiliki proses bisnis utama berupa pelaksanaan proyek konstruksi di bidang indsutri dan manufaktur, PT. Rekind sering menghadapi situasi yang penting dan membutuhkan tanggapan segera. Implementasi push $e$-mail diharapkan dapat meningkatkan daya tanggap pegawai perusahaan terhadap situasi tersebut.
Investasi push e-mail yang akan digunakan PT Rekind bukanlah layanan push e-mail operator jaringan selular, melainkan push e-mail independen yang dinotifikasi melalui SMS. Adanya push e-mail diharapkan dapat mengurangi biaya komunikasi untuk informasi yang penting dan perlu tanggapan segera. Pada kenyataannya tidak semua penyampaian melalui telepon atas informasi penting dan perlu tanggapan segera dapat digantikan dengan push email. Proses bisnis utama PT. Rekind adalah perancangan dan pelaksanaan proyek. Dalam proses bisnis tersebut kategori informasi yang penting dan perlu mendapat tanggapan segera melalui push e-mail adalah yang terkait dengan aktivitas pelaksanaan proyek dan pengontrolan dan pemantauan proyek.

Push e-mail juga diharapkan dapat meningkatkan daya tanggap pegawai dalam proses bisnis yang dilakukannya. Peningkatan daya tanggap ini dihasilkan dari integrasi push e-mail dengan aplikasi perusahaan yang mendukung proses bisnis karena push e-mail memungkinkan proses bisnis dilakukan tanpa dibatasi oleh tempat. Dengan demikian, beberapa potensi kerugian yang disebabkan oleh kurangnya daya tanggap dan aksesibilitas terhadap informasi penting dalam bisnis proses diharapkan dapat ditekan.

Tabel 2. Matriks Strategi Push E-mail

\begin{tabular}{|c|c|c|c|c|}
\hline Pendekatan & Faktor & Rencana & Waktu & Pilihan \\
\hline (Inisiasi) & - & $\begin{array}{l}\text { Implementasi awal push e- } \\
\text { mail dalam sebuah pilot } \\
\text { project dengan kemampuan } \\
\text { meneruskan e-mail baru } \\
\text { yang penting dan perlu } \\
\text { mendapat tanggapan yang } \\
\text { segera. }\end{array}$ & 6 bulan pertama & pilot project \\
\hline Pesimis & $\begin{array}{l}\text { Antusiasme pengguna rendah. } \\
\text { Push e-mail dinilai } \\
\text { bermanfaat sehingga manfaat } \\
\text { yang diharapkan tidak terjadi } \\
\text { karena tidak digunakan secara } \\
\text { optimal }\end{array}$ & $\begin{array}{l}\text { Pilot project di hentikan } \\
\text { untuk menghindari biaya } \\
\text { operasional }\end{array}$ & awal bulan ke-7 & abandon \\
\hline Hati-hati & $\begin{array}{l}\text { Kesulitan teknis yang cukup } \\
\text { tinggi untuk mengintegrasikan } \\
\text { dengan aplikasi perusahaan dan } \\
\text { tidak ada kebutuhan mendesak } \\
\text { untuk itu }\end{array}$ & $\begin{array}{l}\text { Pilot project dipertahankan } \\
\text { sebagai antisipasi kebutuhan } \\
\text { pengembangan lanjut di } \\
\text { masa depan }\end{array}$ & $\begin{array}{l}\text { awal bulan ke-7 } \\
\text { dan awal tahun } \\
\text { kedua }\end{array}$ & continue \\
\hline Optimis & $\begin{array}{l}\text { Kesulitan teknis yang rendah } \\
\text { untuk mengintegrasikan dengan } \\
\text { aplikasi perusahaan dan ada } \\
\text { kebutuhan untuk itu }\end{array}$ & $\begin{array}{l}\text { Pilot project dimutakhirkan } \\
\text { untuk diintegrasikan dengan } \\
\text { aplikasi-aplikasi yang } \\
\text { dimiliki perusahaan. }\end{array}$ & awal tahun kedua & upgrade \\
\hline
\end{tabular}




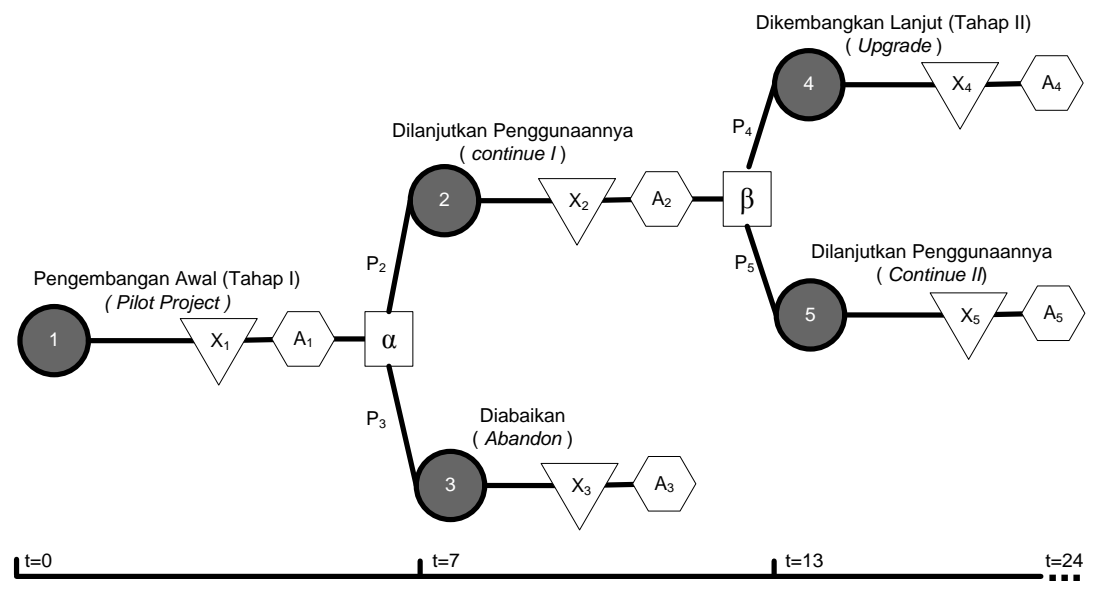

$\mathrm{X}$ : Exercise Price (biaya investasi)

A : Kas Masuk (nilai penghematan)

$\mathrm{P}$ : probabilitas $\alpha$ : keputusan pengabaian (abandonment)

$\beta$ : keputusan upgrade

Gambar 3. Model Binomial Investasi Push E-mail

\subsection{Rencana TI Push E-mail}

Rencana TI untuk push e-mail terdiri dari 2 tahap. Tahap I adalah implementasi awal push e-mail dalam sebuah pilot project yang akan meneruskan $e$ mail biasa yang bersifat informatif dan dikirim oleh pengguna lain.

Pada tahap II, push e-mail diintegrasikan dengan aplikasi-aplikasi yang dimiliki perusahaan sebagai sarana integrasi bisnis proses yang kolaboratif antara berbagai peran yang berbeda. Aplikasi-aplikasi tersebut belum tentu semuanya bisa diakses secara mobile. Untuk itu diperlukan integrasi push e-mail dengan aplikasi yang dimiliki PT Rekind. Dengan implementasi push e-mail tahap II, aktifitas dan aksiaksi bisnis proses yang ada dalam aplikasi seperti request, submit, approval, dan lainnya bisa dilakukan kapan saja dan dimana saja melalui handheld.

\subsection{Perumusan Kerangka Pilihan}

Berdasar rencana TI push e-mail yang ada, disusun strategi implementasinya dalam sebuah matriks strategi.Matriks strategi dibuat dengan memperhitungkan dan mengantisipasi kemungkinan yang akan terjadi pada sebuah rencana investasi. Kerangka pilihan dibuat untuk jangka waktu investasi selama 2 tahun, dengan periode antar tahapan pilihan setiap 6 bulan.

Matriks strategi push e-mail yang didefinisikan diberikan dalam Tabel 2. Pilihan yang tertangkap dari rencana TI dan matriks strategi merupakan compound option sehingga dimodelkan dengan model binomial seperti pada Gambar 3. Rencana TI push e-mail terdiri dari 4 periode waktu yang mencakup 2 tahapan pengambilan keputusan.
Periode pertama berlangsung selama enam bulan pertama $(0 \leq t \leq 6)$, sebelum dilakukan pengambilan keputusan pengabaian (abandonment option). Periode kedua berlaku untuk enam bulan berikutnya $(7 \leq t \leq 12)$ sebelum dilakukan pengambilan keputusan upgrade option. Periode ketiga dan keempat berlangsung selama tahun kedua implementasi $(13 \leq t \leq 24)$. Asumsi nilai suku bunga setiap pada periode $\left(r_{f}\right)$ ialah $5 \%$.

\subsection{Penilaian Deterministik}

Penilaian deterministik dilakukan terhadap kedua tahap pengembangan untuk diketahui nilai finansial dari biaya dan payoff pada masing-masing tahap. Biaya implementasi push e-mail terdiri dari biaya pengembangan dan biaya operasional. Ringkasan biaya development dan biaya operasional untuk tahap I dan II diberikan pada Tabel 3.

Tabel 3. Biaya Implementasi Push E-mail

\begin{tabular}{|l|r|r|}
\hline \multicolumn{1}{|c|}{ Tahap } & $\begin{array}{c}\text { Biaya } \\
\text { Pengembangan }\end{array}$ & $\begin{array}{c}\text { Biaya } \\
\text { Operasional }\end{array}$ \\
\hline Tahap I & 26.650 .000 & 3.400 .000 \\
\hline Tahap II & 31.625 .000 & 8.100 .000 \\
\hline
\end{tabular}

Sementara itu payoff yang akan didapatkan bukan berupa peningkatan pendapatan perusahaan melainkan berupa terjadinya peningkatan efisiensi dalam pelaksanan aktivitas proses bisnis. Investasi push e-mail di perusahaan EPCC seperti halnya PT Rekind tidak berdampak pada kinerja pendapatan perusahaan. Manfaat yang terdeteksi dari pengembangan push e-mail untuk kedua tahap dan nilai finansial yang dihasilkannya adalah seperti yang terdapat dalam Tabel 4. 
Tabel 4. Manfaat Implementasi Push E-mail

\begin{tabular}{|c|c|c|}
\hline Tahap & Manfaat & $\begin{array}{c}\text { Nilai } \\
\text { Finansial } \\
\text { (bulanan) }\end{array}$ \\
\hline Tahap I & $\begin{array}{c}\text { Pengurangan biaya } \\
\text { telekomunikasi }\end{array}$ & 4.400 .000 \\
\hline Tahap II & $\begin{array}{c}\text { Meningkatkan daya } \\
\text { tanggap dan kecepatan } \\
\text { dalam pengambilan } \\
\text { keputusan }\end{array}$ & 35.255 .000 \\
\hline
\end{tabular}

\subsection{Penilaian Resiko}

Implementasi push e-email di PT Rekind memiliki unique risk sekitar $80 \%$ sampai $90 \%$ berdasarkan penilaian subyektif hasil wawancara pegawai Divisi ICT. Angka ini didapat dari pengalaman dan data sejarah mengenai tingkat keberhasilan implementasi aplikasi yang pernah dilakukan oleh Divisi ICT sebelumnya.

Untuk implementasi tahap I diasumsikan tingkat keberhasilannya $\left(p_{2}\right)$ sebesar $90 \%$, sementara tingkat keberhasilan implementasi untuk tahap II $\left(p_{4}\right)$ sebesar $80 \%$. Hal ini disebabkan karena secara teknis implementasi tahap II dinilai lebih sulit daripada tahap I.

\section{Hasil Kajian}

Hasil penghitungan menunjukkan bahwa ROV menghasilkan nilai NPV sebesar Rp.169.782.000,sementara nilai NPV tanpa ROV adalah sebesar Rp.161.350.000,-. Dari angka tersebut terlihat bahwa ROV mampu menilai investasi lebih baik dari pada NPV tanpa real option.

Penghitungan NPV tanpa real option tidak mempertimbangkan adanya fleksibilitas yang terjadi pada investasi. Tidak adanya fleksibilitas menyebabkan rencana implementasi push e-mail harus dipandang secara utuh sebagai satu kesatuan, dan tidak mengakomodasi adanya keputusan terhadap pilihan investasi di masa depan. Sejak awal sudah harus ditetapkan apakah perusahaan akan melakukan implementasi tahap I dan II, walaupun tidak bersamaan, atau tidak sama sekali. Dengan demikian biaya implementasi tahap II tidak dikalikan dengan faktor unique risk seperti halnya biaya dan payoff operasional. Hal ini disebabkan karena implementasi tahap II merupakan sebuah kepastian dan kemungkinan pengeluaran biayanya di tahun kedua ialah sebesar $100 \%$.

Implementasi tahap II tidak dilakukan di tahun pertama bersamaan dengan implementasi tahap I karena rencana TI untuk push e-mail telah menentukan demikian untuk menghindari resiko kegagalan yang terlalu dini. Pada ROV biaya implementasi tahap II dihitung dengan memperhatikan faktor unique risk seperti halnya biaya dan payoff operasional. Ini disebabkan karena implementasi tahap II masih berupa pilihan dan belum tentu dieksekusi. Eksekusi pilihan ini bergantung dari kondisi yang dihadapi di tahun kedua.

Hal lain yang menjadikan adanya selisih antara kedua hasil penghitungan adalah resiko negatif dalam ROV tidak diperhitungkan karena tidak akan dieksekusi. Pada kasus investasi push e-mail PT. Rekind hal ini terjadi dan digambarkan dengan simpul bernomor 3 pada periode $2(t<7 \leq 12)$, yaitu kondisi yang menyebabkan adanya pilihan untuk abandon. Dalam penghitungan nilai $A_{1}$ di atas, nilai negatif dari $0.1(\max [0,15.000-20.400])$ tidak diambil, namun diambil nilai 0 sebagai gantinya. Sementara itu, pada penghitungan NPV biasa nilai negatifnya tetap diperhitungkan seperti yang dapat dilihat pada bagian penghitungan:

\section{$\underline{0.9(26.400-20.400)+\mathbf{0 . 1}(\mathbf{1 5 . 0 0 0}-\mathbf{2 0 . 4 0 0})}$ 1.05}

\section{Kesimpulan}

Penilaian investasi dengan ROV lebih mampu mengapresiasi investasi dibanding metode finansial tradisional, seperti yang ditunjukkan hasil NPV ROV pada kasus investasi push e-mail PT. Rekind yang lebih besar daripada NPV biasa, yaitu Rp.169.782.000,- dibanding Rp.161.350.000,-. Hal ini disebabkan ROV mampu menghargai fleksibilitas dalam investasi yang memiliki pilihan-pilihan rencana investasi di masa depan.

Metode ROV memiliki perbedaan untuk kasus traded asset dan non-traded asset. Parameter ROV untuk traded asset memiliki kemiripan dengan parameter yang dimiliki financial option dimana nilai underlying asset dianalogikan dengan nilai underlying security yang merupakan harga pasar dari asset yang diinvestasikan. Volatilitas underlying asset juga analog dengan volatilitas underlying security, yaitu volatilitas harga pasar dari underlying asset yang diinvestasikan.

ROV untuk investasi TI dikategorikan sebagai kasus non-traded asset jika investasi TI tersebut tidak untuk diperjualbelikan kembali seperti kasus investasi push e-mail PT. Rekind. Karena sifatnya yang tidak diperjualbelikan, kasus non-traded asset tidak memiliki market risk yang nyata sehingga hanya memiliki unique risk saja sebagai unsur volatilitasnya.

ROV dapat dimodelkan dengan model BlackScholes dan model binomial. Menurut [7] model 
Black-Scholes cocok diterapkan untuk kasus simple option, sedangkan model binomial cocok diterapkan pada kasus compound option. Hal ini disebabkan Model Black-Scholes dikembangkan dengan paradigma untuk pilihan tunggal sehingga parameterparameter dari formulanya hanya dapat memiliki sebuah nilai tunggal. Model Black-Scholes dapat saja diaplikasikan untuk compound option, namun hal ini tidak fleksibel karena setiap pengambilan keputusan pilihan memiliki penghitungan formula BlackScholes masing-masing.

\section{REFERENSI}

[1] Amram, M. \& Kulatilaka, N., Real Options Managing Strategic Investment in an Uncertain World, Boston: Harvard Business School Press, 1999.

[2] Hakiman, Model Penentuan Harga IPO di BEJ dengan Metode Real Option, Desertasi
Program Doktor Manajemen Bisnis Universitas Padjadjaran, 2005.

[3] Hevert, Kathleen, Real Options: Valuing Flexibility in Strategic Investments, Babson College Press, 2005.

[4] Cox, J. C. and Rubinstein, M., Options Markets, New York, NY: Prentice-Hall, 1985.

[5] Amram, Martha., Kulatilaka, Nalin., Henderson, John. C., "Taking an Option on IT", CIO Enterprise Magazine, CXO Media Inc, 1999.

[6] Fourt, Robert, "Risk and Optimal Timing in Real Estate Development Using Real Option Analysis", Crystal Ball User Conference, 2004.

[7] Benaroch, Michael, "Managing Information Technology Investment Risk: A Real Option Perspective", Journal of Management Information System, 2002. 